\title{
Jean-Michel Mehl, Des Jeux et des hommes dans la société médiévale
}

G. Matteo Roccati

\section{(2) OpenEdition}

\section{Journals}

Édition électronique

URL : http://journals.openedition.org/studifrancesi/3652

DOI : 10.4000/studifrancesi.3652

ISSN : 2427-5856

Éditeur

Rosenberg \& Sellier

\section{Édition imprimée}

Date de publication : 1 décembre 2012

Pagination : 544

ISSN : 0039-2944

\section{Référence électronique}

G. Matteo Roccati, « Jean-Michel Mehl, Des Jeux et des hommes dans la société médiévale », Studi Francesi [En ligne], 168 (LVI | III) | 2012, mis en ligne le 30 novembre 2015, consulté le 05 mars 2021. URL : http://journals.openedition.org/studifrancesi/3652 ; DOI : https://doi.org/10.4000/studifrancesi. 3652

Ce document a été généré automatiquement le 5 mars 2021.

\section{cc) (1) $\odot$}

Studi Francesi è distribuita con Licenza Creative Commons Attribuzione - Non commerciale - Non opere derivate 4.0 Internazionale. 


\title{
Jean-Michel Mehl, Des Jeux et des hommes dans la société médiévale
}

\author{
G. Matteo Roccati
}

\section{RÉFÉRENCE}

JEAN-MICHEL MEHL, Des Jeux et des hommes dans la société médiévale, Paris, Honoré Champion Éditeur, 2010 («Nouvelle bibliothèque du Moyen Age», 97), pp. 366.

1 Le volume rassemble vingt six études parues précédemment sous forme d'articles entre 1978 et 2005 et qui sont organisées d'une manière cohérente en cinq sections: Possibilités et limites d'une histoire des jeux du Moyen Age et de la Renaissance (place des jeux et leur perception dans la société, le latin des jeux, les lettres de rémission comme source), Autour de Jacques de Cessoles et du jeu d'échecs, Jeux de hasard (les dés), Jeux sportifs (jeu de paume, tir à l'arc, fauconnerie), Des jeux et des hommes (les jeux et les catégories sociales, les jeux de l'enfance, les jeux dans l'éducation, la participation féminine aux activités ludiques, les rois de France et les cartes à jouer). L'ouvrage comporte également une orientation bibliographique (p.345), l'Index nominum et l'index des œuvres. 